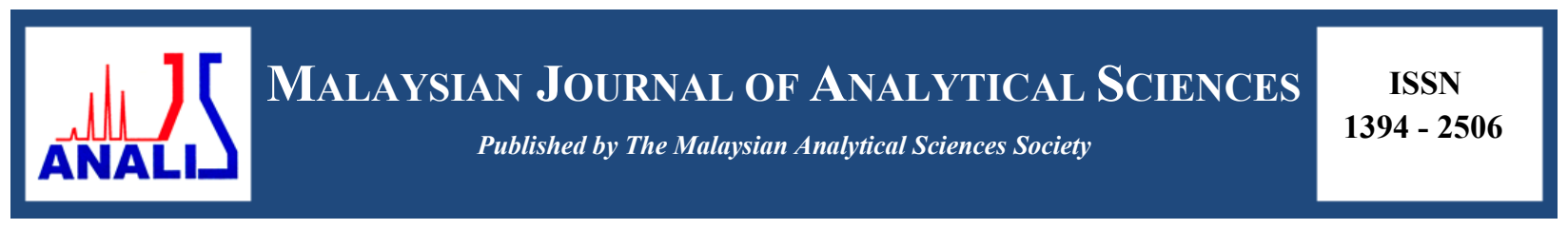

\title{
SYNTHESIS, CHARACTERIZATION AND ELECTOCHEMICAL STUDIES OF 4-METHOXYBENZOYLTHIOUREA DERIVATIVES
}

\author{
(Sintesis, Pencirian dan Kajian Elektrokimia Terhadap Terbitan 4-Metoksibenzoiltiourea) \\ Karimah Kassim ${ }^{1,2 *}$, Noor Khadijah Mustafa Kamal ${ }^{1}$, Adibatul Husna Fadzil ${ }^{3}$. \\ ${ }^{I}$ Faculty of Applied Sciences \\ ${ }^{2}$ Institute of Science \\ Universiti Teknologi MARA, 40450 Shah Alam, Selangor, Malaysia \\ ${ }^{3}$ Faculty of Applied Sciences, \\ Universiti Teknologi MARA (Perak), Kampus Tapah, 35400 Tapah Road, Tapah, Perak, Malaysia \\ *Corresponding author: karimah@salam.uitm.edu.my
}

Received: 17 August 2015; Accepted: 11 October 2016

\begin{abstract}
Three new 4-methoxybenzoylthiourea derivatives namely $N$-phenyl- $N$ '-4-methoxybenzoylthiourea (A), $N$-(2-methoxy-phenyl)$N^{\prime}$-4-methoxybenzoylthiourea (B) and $N$-(2-nitrophenyl)- $N$ '-4-methoxybenzoylthiourea (C) has successfully synthesized and characterized by elemental analysis, Fourier Transform Infrared (FTIR), proton $\left({ }^{1} \mathrm{H}\right)$ and carbon $\left({ }^{13} \mathrm{C}\right)$ Nuclear Magnetic Resonance (NMR) spectroscopy. Result obtained for IR showed the presence of important bands of the compounds such as $v(\mathrm{~N}$ $\mathrm{H}), v(\mathrm{C}=\mathrm{O}), v(\mathrm{C}-\mathrm{N})$ and $v(\mathrm{C}=\mathrm{S})$ which were observed at $3200 \mathrm{~cm}^{-1}, 1670 \mathrm{~cm}^{-1}, 1200 \mathrm{~cm}^{-1}$ and $700 \mathrm{~cm}^{-1}$, respectively. The ${ }^{1} \mathrm{H}$ chemical shifts for $\mathrm{CONH}$ and $\mathrm{CSNH}$ had been observed around $9 \mathrm{ppm}$ and $12 \mathrm{ppm}$, respectively. For the ${ }^{13} \mathrm{C}$ resonance, the signal of $\mathrm{C}=\mathrm{O}$ and $\mathrm{C}=\mathrm{S}$ had been observed at $180 \mathrm{ppm}$ and $200 \mathrm{ppm}$, respectively. The efficiency of the synthesized compounds was investigated as corrosion inhibitor of mild steel in $1.0 \mathrm{M} \mathrm{H}_{2} \mathrm{SO}_{4}$ by using linear polarization resistance (LPR) technique.
\end{abstract}

Keywords: 4-methoxybenzoylthiourea, spectroscopy, corrosion inhibitor

\begin{abstract}
Abstrak
Tiga terbitan 4-metoksibenzoiltiourea iaitu $\quad N$-fenil- $N$ '-4-metoksibenzoiltiourea (A), $N$-(2-metoksifenil)- $N$ '-4-metoksi benzoiltiourea (B) and $N$-(2-nitrofenil)-N'-4- metoksibenzoiltiourea (C) telah berjaya disintesis dan dicirikan dengan penganalisis unsur, spektroskopi infra merah (IR), proton $\left({ }^{1} \mathrm{H}\right)$ dan karbon $\left({ }^{13} \mathrm{C}\right)$ resonans magnet nuklear (RMN). Hasil daripada IR menunjukkan kumpulan penting dalam sebatian seperti $v(\mathrm{~N}-\mathrm{H}), v(\mathrm{C}=\mathrm{O}), v(\mathrm{C}-\mathrm{N})$ and $v(\mathrm{C}=\mathrm{S})$ yang terdapat pada $3200 \mathrm{~cm}^{-1}$, $1670 \mathrm{~cm}^{-1}, 1200 \mathrm{~cm}^{-1}$ and $700 \mathrm{~cm}^{-1}$. Anjakan kimia ${ }^{1} \mathrm{H}$ untuk CONH dan CSNH telah dilihat pada $9 \mathrm{ppm}$ dan $12 \mathrm{ppm}$. Bagi resonans ${ }^{13} \mathrm{C}, \mathrm{C}=\mathrm{O}$ dan $\mathrm{C}=\mathrm{S}$ dapat dilihat pada $180 \mathrm{ppm}$ dan $200 \mathrm{ppm}$. Keberkesanan sebatian yang disintesis telah dikaji sebagai perencat kakisan keluli lembut dalam $1.0 \mathrm{M} \mathrm{H}_{2} \mathrm{SO}_{4}$ dengan menggunakan teknik rintangan polarisasi linear.
\end{abstract}

Kata kunci: 4-metoksibenzoiltiourea, spektroskopi, perencat kakisan

\section{Introduction}

Corrosion prevention by using organic inhibitors is one the most practical ways to protect metal in acidic medium [1] The studies on it had attracted many attentions of researchers [2,3]. Corrosion inhibitors are substances that may retard or slow down the corrosion rate when added in small concentration to the system. Organic inhibitors containing nitrogen $(\mathrm{N})$, sulphur $(\mathrm{S})$ and oxygen $(\mathrm{O})$ atoms are considered to be the effective and potential corrosion inhibitors [3-6]. The inhibitors that have these atoms in their structure may induce greater adsorption of the 


\section{Karimah et al: SYNTHESIS, CHARACTERIZATION AND ELECTOCHEMICAL STUDIES OF 4-METHOXYBENZOYLTHIOUREA DERIVATIVES}

compounds onto the metal surfaces which leads to the formation of a corrosion protecting film. In addition, the stability of the adsorbed inhibitor film on the metal surface also depends on functional groups $[9,11,12]$.

Thiourea and its derivatives were reported to be the potential corrosion inhibitors as compared with other organic compounds because thiourea molecules contain one $\mathrm{S}$ atom and two $\mathrm{N}$ atoms [6-8]. These atoms act as centre of adsorption that forms a protective layer on the metal surface from the corrosive attack [9-10]. The corrosion inhibition of thiourea is greater in acidic media because this inhibitor acts simultaneously in both anodic and cathodic areas. Thiourea molecules are very effective inhibitors for steel in acidic conditions because $\mathrm{S}$ atom is easily protonated in acidic solution and a stronger electron donor than nitrogen [16].

In this study, a series of 4-methoxybenzoylthiourea derivatives with different substituent groups were synthesized and tested as potential corrosion inhibitor in $1.0 \mathrm{M} \mathrm{H}_{2} \mathrm{SO}_{4}$ to achieve inhibition efficiency more than $90 \%$. The effect of different substituent group on the inhibition efficiency at different inhibitors' concentrations were also has been studied.

\section{Physical measurement}

\section{Materials and Methods}

All reactions were performed under an ambient atmosphere and no special precautions were taken to exclude air or moisture. The chemicals (4-methoxybenzoyl chloride, ammonium thiocyanate, aniline, $o$-Anisidine, 2-nitroaniline) and solvents (acetone and acetonitrile) were purchased from Sigma Aldrich and were used without further purification. Melting points were measured using BÜCHI Melting Point B-545. Infrared spectra were recorded using FTIR Perkin Elmer 100 Spectrophotometer in the spectral range of 4000 to $400 \mathrm{~cm}^{-1}$ by using $\mathrm{KBr}$ pellet. ${ }^{1} \mathrm{H}$ and ${ }^{13} \mathrm{C}$ NMR spectra were obtained from Bruker Advance III 300 Spectrometer at room temperature. The elemental analyses of compound were performed by CHNS Analyzer FLASH 2000 series.

\section{Synthesis of $N$-phenyl- $N$ '-4-methoxybenzoylthiourea (A)}

Freshly prepared $5 \mathrm{mmol}(0.85 \mathrm{~g})$ of 4-methoxybenzoyl chloride in $15 \mathrm{ml}$ acetone was added to equal molar of ammonium thiocyanate $(0.38 \mathrm{~g})$. The solution was stirred about $20 \mathrm{~min}$. The precipitate formed was discarded and the solution was kept. An amount of $5 \mathrm{mmol}(0.46 \mathrm{ml})$ of aniline was mixed with the previous solution and undergo refluxed for 3 hours. The solution was poured into a beaker containing ice cubes. The resulting precipitate was collected by filtration, washed ethanol and purified by recrystallization with acetonitrile. Figure 1 show the chemical structure of $N$-phenyl- $N$ '-4-methoxybenzoyl thiourea (A).<smiles>COc1ccc(C(=O)NC(=S)Nc2ccccc2)cc1</smiles>

Figure 1. Chemical structure of $N$-phenyl- $N$ '-4-methoxybenzoyl thiourea (A)

\section{Synthesis of $N$-(2-methoxyphenyl)- $N$ '-4-methoxybenzoylthiourea (B)}

Similar procedure as the above, this compound was synthesized by reacting 4 -methoxybenzoyl chloride ( $5 \mathrm{mmol}$, $0.85 \mathrm{~g})$, ammonium thiocyanate $(5 \mathrm{mmol}, 0.38 \mathrm{~g})$ and $o$-Anisidine $(5 \mathrm{mmol}, 0.62 \mathrm{~g})$. Figure 2 show the chemical structure of N-(2-methoxyphenyl)-N'-4-methoxybenzoyl thiourea (B). 
<smiles>COc1ccc(C(=O)NC(=S)Nc2ccccc2OC)cc1</smiles>

Figure 2. Chemical structure of $N$-(2-methoxyphenyl)- $N$ '-4-methoxybenzoyl thiourea (B)

\section{Synthesis of $N$-(2-nitrophenyl)- $N$ '-4-methoxybenzoylthiourea (C)}

This compound was prepared by similar procedure as above with 4-methoxybenzoyl chloride $(5 \mathrm{mmol}, \quad 0.85 \mathrm{~g})$, ammonium thiocyanate $(5 \mathrm{mmol}, 0.38 \mathrm{~g}$ ) and 2-nitroaniline $(5 \mathrm{mmol}, 0.69 \mathrm{~g})$. Figure 3 show the chemical structure of N-(2-nitrophenyl)-N'-4-methoxybenzoyl thiourea (C)<smiles>COc1ccc(C(=O)NC(=S)Nc2ccccc2[N+](=O)[O-])cc1</smiles>

Figure 3. Chemical structure of $N$-(2-nitrophenyl)- $N$ '-4-methoxybenzoyl thiourea (C)

\section{Linear polarization resistance (LPR) technique}

This method was carried out in a three-electrode cells consist of Silver-silver chloride $(\mathrm{Ag} / \mathrm{AgCl})$ as a reference electrode, platinum as a counter electrode and the mild steel sample as working electrode. The working electrode was prepared by embedding a rod with a mild steel sample in epoxy resin. The exposed surface area of the sample was $0.065 \mathrm{~cm}^{2}$. The measurements by AUTOLAB potentiostat/galvanostat instrument equipped with NOVA software. The polarization curves were recorded at a rate of $0.5 \mathrm{mV} \mathrm{s}^{-1}$. Prior to analysis, the working electrode was polished with emery paper, washed with distilled water, dried and finally immersed in the tested solution for an hour to achieve steady state. The tested solution used was sulphuric acid $\left(\mathrm{H}_{2} \mathrm{SO}_{4}\right)$ with or without compound $\mathrm{A}$, $\mathrm{B}$ and $\mathrm{C}$.

\section{Physical measurement}

\section{Results and Discussion}

Table 1 shows the percentage yield, colour, melting point and elemental percentage of compound A, B and C. The composition values of the calculated and experimental for elemental analysis are in good agreement. Meanwhile, Table 2 shows the important FTIR adsorption bands, ${ }^{1} \mathrm{H}$ and ${ }^{13} \mathrm{C}$ NMR chemical shifts for the three compounds.

Table 1. Percentage yield, colour, melting point and elemental analysis for compound A, B and C

\begin{tabular}{|c|c|c|c|c|c|c|c|}
\hline \multirow{2}{*}{ Compound } & \multirow{2}{*}{$\begin{array}{c}\text { Percentage } \\
\text { yield }(\%)\end{array}$} & \multirow{2}{*}{ Colour } & \multirow{2}{*}{$\begin{array}{c}\text { Melting } \\
\left.\text { point ( }{ }^{\circ} \mathbf{C}\right)\end{array}$} & \multicolumn{4}{|c|}{ Elemental analysis (Experimental) (\%) } \\
\hline & & & & C & $\mathbf{H}$ & $\mathbf{N}$ & $\mathbf{S}$ \\
\hline A & 52.9 & White & 140 & $\begin{array}{c}62.94 \\
(61.00)\end{array}$ & $\begin{array}{c}4.90 \\
(4.92)\end{array}$ & $\begin{array}{c}9.79 \\
(9.06)\end{array}$ & $\begin{array}{c}11.19 \\
(10.42)\end{array}$ \\
\hline $\mathrm{B}$ & 63.1 & White & 138 & $\begin{array}{c}60.76 \\
(60.84)\end{array}$ & $\begin{array}{c}5.06 \\
(4.95)\end{array}$ & $\begin{array}{c}8.86 \\
(8.56)\end{array}$ & $\begin{array}{l}10.12 \\
(9.29)\end{array}$ \\
\hline $\mathrm{C}$ & 58.7 & White & 142 & $\begin{array}{c}54.38 \\
(59.46)\end{array}$ & $\begin{array}{c}5.06 \\
(4.31)\end{array}$ & $\begin{array}{c}12.69 \\
(10.87)\end{array}$ & $\begin{array}{c}9.67 \\
(8.50)\end{array}$ \\
\hline
\end{tabular}


Table 2. FTIR absorption bands, NMR proton $\left({ }^{1} \mathrm{H}\right)$ and carbon $\left({ }^{13} \mathrm{C}\right)$ shifts for compound A, B and C

\begin{tabular}{|c|c|c|c|c|c|c|c|c|}
\hline \multirow[b]{2}{*}{ Compound } & \multirow[b]{2}{*}{$\mathbf{v}(\mathrm{NH})$} & \multicolumn{2}{|c|}{ FTIR } & & \multicolumn{2}{|l|}{ NMR } & \multicolumn{2}{|c|}{13} \\
\hline & & $v(C=O)$ & $v(C N)$ & $\mathbf{v}(\mathrm{C}=\mathrm{S})$ & CONH & CSNH & $\mathrm{C}=\mathrm{O}$ & $\mathbf{C}=\mathbf{S}$ \\
\hline A & 3338.89 & 1655.58 & 1179.81 & 690.91 & 9.07 & 12.80 & 179.20 & 206.97 \\
\hline B & 3222.93 & 1667.92 & 1221.54 & 712.89 & 9.03 & 12.90 & 179.06 & 207.15 \\
\hline $\mathrm{C}$ & 3247.56 & 1670.21 & 1178.62 & 708.25 & 9.10 & 12.85 & 177.06 & 207.17 \\
\hline
\end{tabular}

\section{Linear polarization resistance}

The polarization curves of mild steel in $1.0 \mathrm{M} \mathrm{H}_{2} \mathrm{SO}_{4}$ in the absence and presence of 4-methoxybenzoyl thiourea derivatives are shown in Figures $4-6$. The corrosion parameters such as corrosion potential $\left(\mathrm{E}_{\text {corr }}\right)$, corrosion current density $\left(\mathrm{i}_{\text {corr }}\right)$, anodic Tafel slope $\left(\mathrm{b}_{\mathrm{a}}\right)$, cathodic Tafel slope $\left(\mathrm{b}_{\mathrm{c}}\right)$ and inhibition efficiency (IE\%) are listed in Table 3. As compared with the $\mathrm{H}_{2} \mathrm{SO}_{4}$ without the presence of any inhibitor or also known as blank, it can be observed that $i_{\text {corr }}$ decrease in the presence of the inhibitors and decrease as the concentration of the inhibitors increases. The decrease of these values with the presence of inhibitor and increasing inhibitors concentration indicates that there are inhibiting natures of the thiourea derivatives $[13,14]$.

Table 3. LPR parameters of mild steel in $1.0 \mathrm{M} \mathrm{H}_{2} \mathrm{SO}_{4}$ containing different concentrations of $\mathrm{A}, \mathrm{B}$ and $\mathrm{C}$

\begin{tabular}{lccccccc}
\hline Compound & $\begin{array}{c}\text { Concentration } \\
(\mathbf{M})\end{array}$ & $\begin{array}{c}\mathbf{b}_{\mathbf{a}} \\
(\mathbf{V} / \mathbf{d e c})\end{array}$ & $\begin{array}{c}\mathbf{b}_{\mathbf{c}} \\
(\mathbf{V} / \mathbf{d e c})\end{array}$ & $\begin{array}{c}\mathbf{E}_{\text {corr }} \\
(\mathbf{V})\end{array}$ & $\begin{array}{c}\mathbf{i}_{\text {corr }} \\
\left(\mathbf{A} / \mathbf{c m}^{2}\right)\end{array}$ & $\begin{array}{c}\text { Corrosion rate } \\
(\mathbf{m m} / \mathbf{y e a r})\end{array}$ & $\begin{array}{c}\text { IE } \\
\mathbf{\%}\end{array}$ \\
\hline Blank & - & 0.1339 & 0.0380 & -0.4287 & $2.02 \mathrm{E}-04$ & 2.3425 & - \\
$\mathrm{A}$ & $1 \times 10^{-5}$ & 0.0308 & 0.0214 & -0.4119 & $5.83 \mathrm{E}-05$ & 0.6767 & 71.1 \\
& $1 \times 10^{-4}$ & 0.1138 & 0.0256 & -0.3941 & $5.39 \mathrm{E}-05$ & 0.6258 & 73.3 \\
& $1 \times 10^{-3}$ & 0.0618 & 0.0208 & -0.3693 & $4.13 \mathrm{E}-05$ & 0.47919 & 79.6 \\
$\mathrm{~B}$ & $1 \times 10^{-5}$ & 0.1042 & 0.0349 & -0.4045 & $6.53 \mathrm{E}-05$ & 0.7581 & 67.7 \\
& $1 \times 10^{-4}$ & 0.0697 & 0.0258 & -0.3944 & $3.48 \mathrm{E}-05$ & 0.4036 & 82.8 \\
& $1 \times 10^{-3}$ & 0.0570 & 0.0199 & -0.3744 & $2.60 \mathrm{E}-05$ & 0.3017 & 87.1 \\
$\mathrm{C}$ & $1 \times 10^{-5}$ & 0.1282 & 0.0406 & -0.4226 & 0.00012 & 1.3890 & 40.6 \\
& $1 \times 10^{-4}$ & 0.0665 & 0.0340 & -0.4110 & $6.43 \mathrm{E}-05$ & 0.7460 & 68.2 \\
& $1 \times 10^{-3}$ & 0.1225 & 0.0460 & -0.3900 & $6.36 \mathrm{E}-05$ & 0.7386 & 77.6 \\
\hline
\end{tabular}




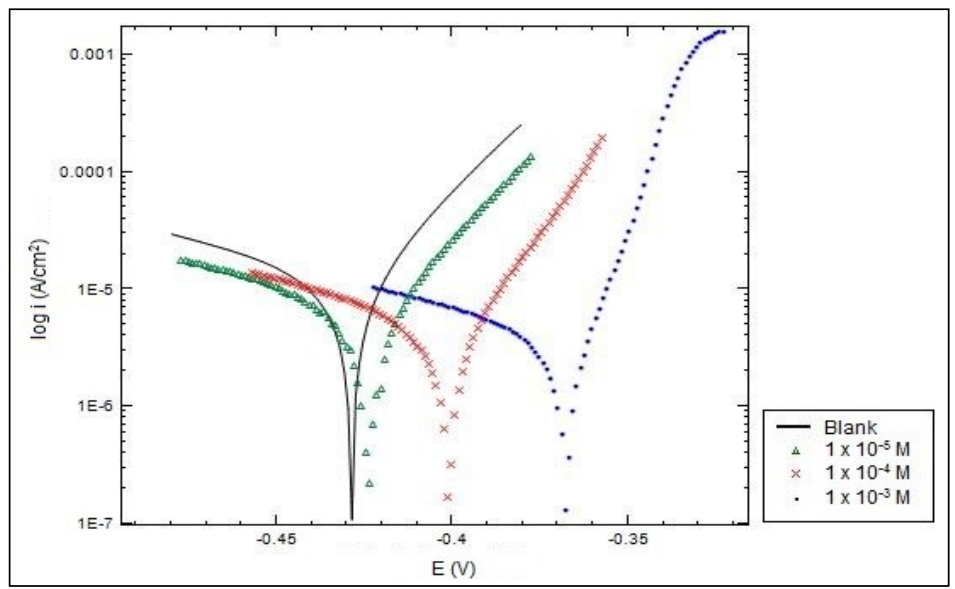

Figure 4. Polarization curves of various concentration of compound $\mathrm{A}$ in $1.0 \mathrm{M} \mathrm{H}_{2} \mathrm{SO}_{4}$

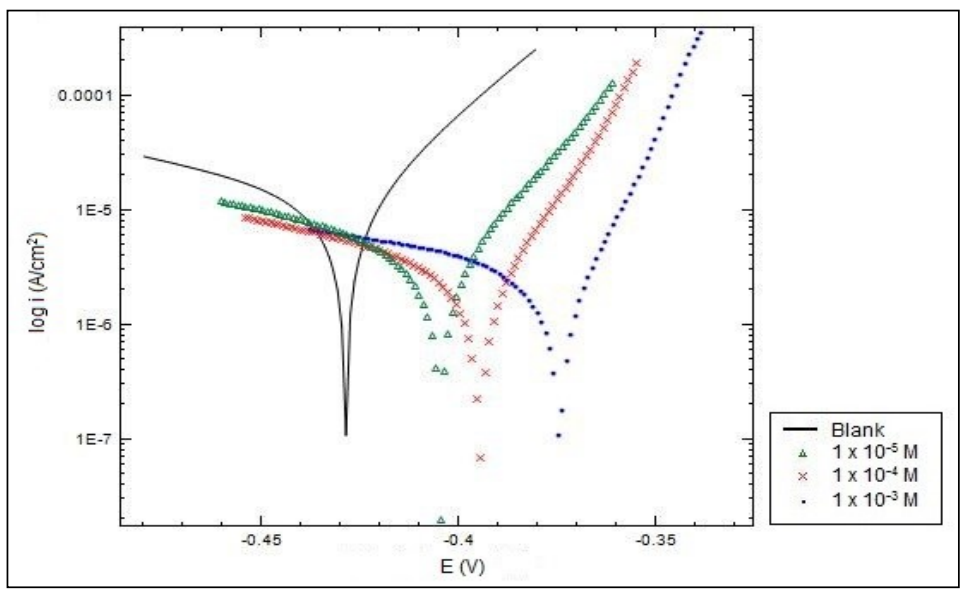

Figure 5. Polarization curves of various concentration of compound $\mathrm{B}$ in $1.0 \mathrm{M} \mathrm{H}_{2} \mathrm{SO}_{4}$

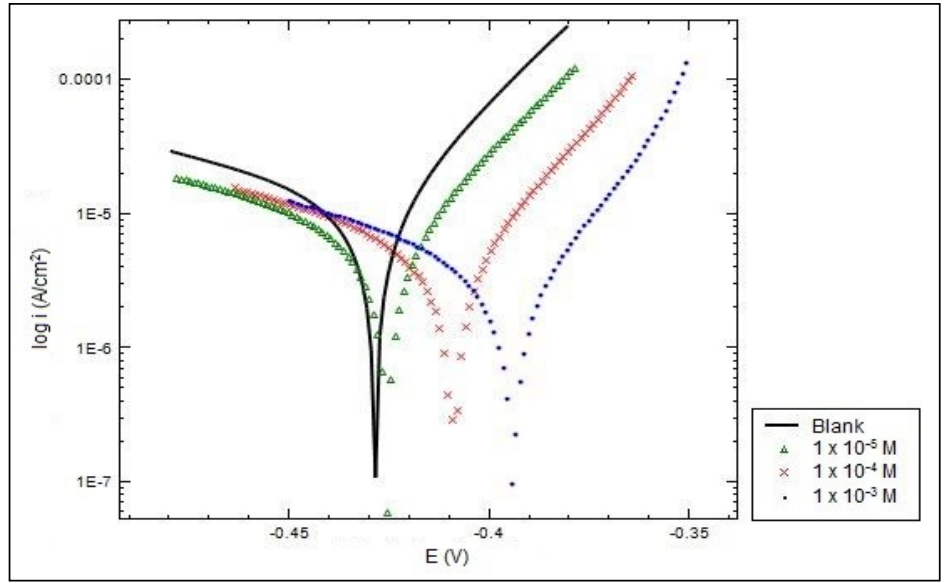

Figure 6. Polarization curves of various concentration of compound $\mathrm{C}$ in $1.0 \mathrm{M} \mathrm{H}_{2} \mathrm{SO}_{4}$ 


\section{Karimah et al: SYNTHESIS, CHARACTERIZATION AND ELECTOCHEMICAL STUDIES OF 4-METHOXYBENZOYLTHIOUREA DERIVATIVES}

From Table 3, the $\mathrm{E}_{\text {corr }}$ values shown slight changes in the presence of the inhibitors. This means that the thiourea derivatives are mixed-type inhibitor in $1.0 \mathrm{M} \mathrm{H}_{2} \mathrm{SO}_{4}$. In addition, the average displacement of $\mathrm{E}_{\text {corr }}$ is not more than $85 \mathrm{mV}$, which suggest that these compounds are mixed-type inhibitors [13] even though the polarization curves shift toward the positive side with respect to blank. It also can be observed that the values of $b_{c}$ did not change drastically with the addition of the compounds showing that thiourea derivatives did not affect the hydrogen evolution reaction [9]. The changes in $b_{a}$ values with the inhibitors concentration shows that may alter the metal dissolution process. Results from this technique shows that the efficiency of these compounds increased as the concentration of corrosion inhibitor increased. The IE\% of the inhibitor was calculated based on the $\mathrm{i}_{\text {corr }}$ values obtained from the measurement using the following formula equation 1 [15]:

$$
\mathrm{IE} \%=\frac{{ }^{\prime} \text { corr }^{-} \mathrm{I}_{\text {corr }}}{\mathrm{I}_{\text {corr }}}
$$

where I' corr and $\mathrm{I}_{\text {corr }}$ are the corrosion current densities in the absence and presence of an inhibitor, respectively.

Among these three compounds, compound B has the highest IE\% which is $87.1 \%$. The presence of different substituent in each compounds affect the IE\%. Since compound B has methoxy substituent which is classified as electron donating group, it donates electrons to the system and make it electron rich. This enables the compound to form a protective layer on the metal surface. Unlike compound $\mathrm{C}$ which posses electron withdrawing group substituent $\left(\mathrm{NO}_{2}\right)$, the substituent will withdraw electrons from the system and make it unstable. Thus, forming a less effective layer. The order of the effectiveness of the compounds as corrosion inhibitors are B $>\mathrm{A}>\mathrm{C}$.

\section{Conclusion}

$N$-phenyl- $N$ '-4-methoxybenzoylthiourea (A), $N$-(2-methoxyphenyl)- $N$ '-4-methoxybenzoylthiourea (B) and $N$-(2nitrophenyl)- $N$ '-4-methoxybenzoylthiourea (C) has been successfully synthesized and characterized. Compound B with methoxy substituent has the highest IE\% which is $87.1 \%$. This compound has the potential as an effective corrosion inhibitor that can be used in acid pickling process in chemical or petroleum industries.

\section{Acknowledgement}

The authors are grateful to the Ministry of Higher Education of Malaysia for the research grant no. 600FRGS/2/2013/ST01/UITM/02/6 and the Faculty of Applied Sciences, Institute of Science and Universiti Teknologi MARA for providing research facilities.

\section{References}

1. Likhanova N. V., Olivares-Xometl O., Guzmán-Lucero D., Domínguez-Aguilar M. A., Nava N., Corrales-Luna M. and Mendoza M. C. (2011). Corrosion inhibition of carbon steel in acidic environment by imidazolium ionic liquids containing vinyl-hexafluorophosphate as anion. International Journal of Electrochemical Science, 6: $4514-4536$.

2. Kadhum A. A. H., Mohamad A. B., Hammed L.A., Al-Amiery A. A., San N. H and Musa A. Y. (2014). Inhibition of mild steel corrosion in hydrochloric acid solution by new coumarin. Materials, 7: $4335-4348$.

3. Selvakumar P., Karthik B.B. and Thangavelu C. (2013). Corrosion inhibition study of stainless steel in acidic medium - An overview. Research Journal of Chemical Sciences, 3(4): 87 - 95.

4. Yaro A. S. and Abdulaaima D. A. (2012). Phenyl thiourea as corrosion inhibitor for mild steel in strong hydrochloric acid. Iraqi Journal of Chemical and Petroleum Engineering, 13(2): 1 - 9.

5. Karthikeyan S., Harikumar S., Venkatachalam G., Naranayan S. and Venckatesh R. (2012). The inhibitive action of cyclohexyl thiourea on the corrosion and hydrogen permeation through mild steel in acidic solutions. International Journal of ChemTech Research, 4(3): 1065 - 1071.

6. Gopiraman M., Selvakumaran N., Kesavan D. and Karvembu R. (2012). Adsorption and corrosion inhibition behaviour of $\mathrm{N}$-(phenylcarbamothioyl)benzamide on mild steel in acidic medium. Progress in Organic Coatings, 73: $104-111$.

7. Edrah S. and Hasan. S. K. (2010). Studies on thiourea derivatives as corrosion inhibitor for aluminum in sodium hydroxide solution. Journal of Applied Science Research, 6: 1045 - 1049.

8. Khaled K. F. (2010). Experimental and molecular dynamic study on the inhibition performance of some nitrogen containing compounds for iron corrosion. Material Chemistry and Physics, 124: 760 -767. 
9. Torres V. V., Rayol V. A., Magalhães M., Viana G. M., Aguiar L. C. S, Machado S. P., Orofino H. and D’Elia E. (2014). Study of thiourea derivatives synthesized from a green route as corrosion inhibitors for mild steel in $\mathrm{HCl}$ solution. Corrosion Science, 79: 108 - 118.

10. Torres V. V., Amado R. S., de Sá C. F., Fernandez T. L., Riehl C. A. S., Torres A. G, and D’Elia E. (2011). Inhibitory action of aqueous coffee ground extracts on the corrosion of carbon steel in $\mathrm{HCl}$ solution. Corrosion Science, 53: $2385-2392$.

11. Khaled K. F. (2010). Experimental, density function theory calculations and molecular dynamics simulations to investigate the adsorption of some thiourea derivatives on iron surface in nitric acid solutions. Applied Surface Science, 256: $6753-6763$.

12. Sanyal B. (1981). Organic compounds as corrosion inhibitors in different environments - A review. Progress in Organic Coating. 9: $165-236$.

13. Gopiraman M., Selvakumaran N., Kesavan D., Kim I. S. and Karvembu R. (2012). Chemical and physical interactions of 1-benzoyl-3,3-disubstituted thiourea derivatives on mild steel surfaces: Corrosion inhibition in acidic media. Industrial \& Engineering Chemistry Research, 51: 7910 - 7922.

14. Li X., Deng S. and Fu H. Allyl thiourea as a corrosion inhibitor for cold rolled steel in $\mathrm{H}_{3} \mathrm{PO}_{4}$ solution. Corrosion Science, 55: 280 - 288.

15. Tang T., Zhang F., Hu S., Cao Z., Wua Z. and Jing W. (2013). Novel benzimidazole derivatives as corrosion inhibitors of mild steel in the acidic media. Part I: Gravimetric, electrochemical, SEM and XPS studies. Corrosion Science, 74: $271-282$

16. Ali, S.A., Saeed, M.T. and Rahman, S.V. (2003). The Isoxazolidines: A new class of corrosion inhibitors of mild steel in acidic medium, Corrosion Science, 45 (2): 253 - 266. 